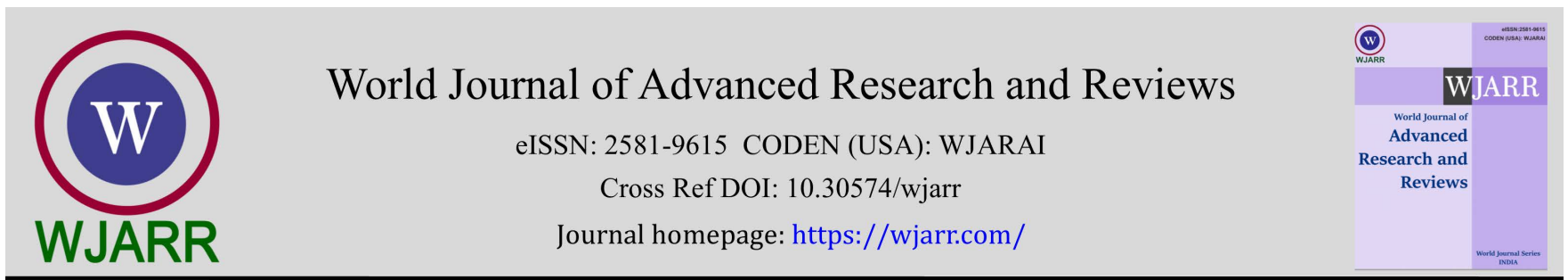

(RESEARCH ARTiClE)

\title{
Assessment of knowledge and practice of criminal intelligence and staff profiling for fraud prevention in Nigerian banks
}

\author{
Osugba Sylvester * and Onyige Chioma \\ Department of Sociology, University of Port Harcourt, Nigeria.
}

World Journal of Advanced Research and Reviews, 2022, 13(02), 429-432

Publication history: Received on 14 January 2022; revised on 18 February 2022; accepted on 20 February 2022

Article DOI: https://doi.org/10.30574/wjarr.2022.13.2.0165

\begin{abstract}
The study was set to examine knowledge and practice of criminal intelligence and staff profiling for fraud prevention in Nigerian banks, the study adopted the mixed method research design of descriptive survey and key informant interview. Multistage sampling technique was used to select the sample population for the study a total of 324 respondents was sampled using the Taro Yamane formula for sample size determination. Questionnaire and key person's interview were used as data collection instrument. The findings of the study conclude that bank staff is aware and knowledgeable of criminal intelligence and staff profiling as an effective tool for fraud prevention. Beyond the awareness, bank staff are also knowledgeable on the application of criminal intelligence and staff profiling, while they also agreed that the extent of application of criminal intelligence and staff profiling in the recruitment, placement and monitoring of staff is low. However, the study recommends that Senior management of banks should be given adequate training and this training should be regularly updated on criminal intelligence and monitoring, as well as staff profiling. This would facilitate a greater uptake of credible intelligence and the prevention of bank fraud and other criminal activities.
\end{abstract}

Keywords: Assessment; Knowledge; Practice; Criminal Intelligence; Staff Profiling; Fraud; Prevention

\section{Introduction}

The increasing cases of robbery and fraud involving bank staff is alarming and theinability of banks and financial institutions to prevent, unearth, identify and prevent the involvement of staff in fraud and robbing of their organizations in spite of the availability of reliable technological tools has remained a question unanswered. According to NDIC annual report (2010) in 1998 about N 689.2 million, N2730.57 million in 1999, N2851.1 million in 2000 and N11,243.98 million in 2001 were lost to fraud. [1] did not only acknowledge the endemic and escalating nature of fraud that was re-echoed by the description of KPMG (2009) which described fraud as an industry not just for fraudsters but academics should study. Investigators investigate it; lawyers litigate on it, and conference attendees debate on it. However, the industry is built on the logic of managing the consequences of fraud rather than preventing it.

In 2005, there was a reform in the Nigerian banking sector to avert imminent collapse. The reform was characterized largely by mergers and acquisitions of many banks to the extent that only 25 banks emerged out of 89 after the exercise. Nevertheless, the threat of fraud has continued. According to Nigerian Deposit Insurance Corporation (NDIC) Annual Report (2010), 1,532 cases of fraud were reported involving 21.29 billion naira with expected actual loss of 11.69 billion naira. Also, in 2011, 2,352 cases of fraud were reported involving 28.4 billion naira with expected actual loss of 4.071 billion naira. This represents a 53.5 percent increase. In 2014, there were 10,612 reported cases of fraud as against 3,786 in 2013 with involvement of 25.61 billion naira and 21.80 billion naira respectively. This represents about 17.5 percent increase in amount involved. The expected actual loss for 2014 was 6.19 billion naira as against 5.76 billion naira in 2013, representing an increase of about 7.5 percent.

\footnotetext{
${ }^{*}$ Corresponding author: Osugba Sylvester

Department of Sociology, University of Port Harcourt, Nigeria.

Copyright $(2022$ Author(s) retain the copyright of this article. This article is published under the terms of the Creative Commons Attribution Liscense 4.0.
} 
In 2009, Central Bank of Nigeria while employing the services of Forensic Accountants uncovered fraud in five commercial banks. As a result, the Chief Executive Officer of Oceanic Bank was prosecuted by Economic and Financial Crimes Commission (EFCC) and was sentenced by the court on conviction to 18 months [2].

It has been observed that reported cases of bank fraud have been on the increase, but its impact on the Nigerian banking sector is of great concern (NDIC, 2015). There has been studies on the impact of fraud on Nigerian banks by scholars like [3], [4], [5], [6], [7] and [8], in which most of them looked at it from the number and classes of staff involved and the causes of fraud in the banking industry. On bank staff involvement on fraud, it was discovered that in 2002, a total of 85 staff were reported to be involved in fraud and forgeries with Officers/Accountants and Executive Assistant representing more than 50\% [5]. Furthermore, a total of 106 staff were involved in 2003, representing an increase of about $24.7 \%$ above the previous year. Owolabi, further stated that staff that were in the core banking operations such as supervisors, accountants, officers, executive assistants, clerks and cashier accounted for about 85.84 percent, a decrease of about 4.8 percent from year 2002. However, in 2004, there was an increase in the number of staff that participated in fraud and forgeries in the banking industry, as a total number of 383 staff was involved representing about $46.7 \%$ when compared with the previous years' level. Staff in the core operations accounted for 90.60 percent an increase of 4.76 percent compared to 2003. This is an indication that more staff were getting involved in fraudulent practices and 378 staff were connected with fraudulent cases in 2005.This shows a little decrease from year 2004 by about 1.30 percent. A total of 331 banks staff were involved in frauds and forgeries in the year 2006; indicating a decrease of $14.19 \%$ compared with the previous year's figure of 378 . For core operating staff a total of 258 representing about 77. 93 percent which indicate a decrease of 13.85 percent relative to the 2005 level. This means that Staff involvement in fraudulent practices between 2001 and 2006 managers and supervisors were more involved. He concluded that there is unprecedented geometrical increment in the temporary staff involvement which rose from 3 in 2005 to 50 in 2006 . However, the study by [9] revealed that bank staff do not see unofficial borrowing and foreign exchange malpractices as a form of bank fraud. Nevertheless, [10] examined categories of bank staff involved in the fraud and forgeries. It was found that from 2003-2009, a period of 7 years, a total of 656 members of bank staff were involved in 2,440 cases of frauds and forgeries with core operating staff numbering 431 involved; that is 65.7 per cent.

In 2017, 320 cases of fraud and forgery were staff-related, representing $1.22 \%$ of the entire f frauds cases. This represents an increase of $38.5 \%$ from 231 cases reported in 2016 but declined by $31.2 \%$ and $24.7 \%$ from 425 and 465 cases recorded in 2014 and 2015, respectively. Some of the staff included is Officers and Executive Assistants, as well as Managers accounting for $25.9 \%$ and $21.3 \%$ of the total fraud cases during the year. While messengers, drivers, cleaners, security guards constituted $4.1 \%$ of the total fraud cases. This has further reinforced the need for a more proactive measures by Deposit Money Banks Management to help identify potential weaknesses by employing adequate checks and balances to protect the institution. According [11] between January and June of 2017, the total reported incidents of attempted and successful frauds/forgeries in the banking sector was sixteen thousand, seven hundred and sixty-two $(16,762)$. This was valued at N5.52 billion. In the end, however, the banks only incurred a total loss of N0.78 billion in the first quarter of 2017 compared to the N12 billion that was lost in first quarter of 2018 which constitute about 38 per cent increase. Central Bank further asserted that these crimes were perpetrated by both staff of banks and other criminals. Therefore, the nature of the crimes is such that it involved fraudulent ATM withdrawals, illegal transfer of funds, armed robbery attacks, cash pilfering, defalcation, the suppression and conversion of customers' deposits, etc. amidst the increasing rate of fraud in Nigerian banks, this study is poised to assess knowledge and practice of criminal intelligence and staff profiling for fraud prevention in Nigerian banks.

\section{Methodology}

The study adopted the mixed method research design of descriptive survey and key informant interview. Multistage sampling technique was used to select the sample population for the study, a total of 324 respondents with four (4) staff from each head offices from each commercial bank totalling 216 with 1(one) Private security personnel totalling 54 and 1(one) Government security (police) from each of the 18 commercial bank head office, (attached to banks) totalling 54. A 35 items questionnaire was used as the instrument for data collection alongside Key Informant Interview which were conducted using, all Heads of the banks to tap into their experience on staff involvement in fraud and to get their opinion on criminal intelligence and consistent staff profiling, Convicted Bankers or fraudsters on fraud to know what motivated them to get involved in fraud; what are the loopholes in the banking industry that made it possible for them to carry out fraud; and how it can be prevent, Convicted bank robbers to get information about their experience on how these robberies were planned and how much help they get from insiders; what kind of people they get involved with to get information and what can be done to prevent this situation and security agencies like the Police attached to banks to explore their experience on the subject matter and how it can be prevented. 


\section{Results and discussion}

The result as shown in table 1 with respect to awareness of criminal intelligence and staff profiling as a tool for fraud prevention in Nigerian Banks reveals that 267 respondents which represents $84.5 \%$ reported being aware of criminal intelligence and staff profiling as a tool for fraud prevention in Nigerian Banks, while 49 respondents which represents $15.50 \%$ reported not being aware of criminal intelligence and staff profiling as a tool for fraud prevention in Nigerian Banks. From this results, it is indicative that majority of the respondents are aware of criminal intelligence and staff profiling as a tool for fraud prevention in Nigerian Banks.

Table 1 Awareness of criminal intelligence and staff profiling as a tool for Fraud prevention in Nigerian Banks

\begin{tabular}{|c|c|c|}
\hline Response & Frequency & Percentage \% \\
\hline Yes & 267 & 84.5 \\
\hline No & 49 & 15.5 \\
\hline Total & 316 & 100.0 \\
\hline
\end{tabular}

This finding is also corroborated by the responses obtained from the key informant interviews.

\subsection{According to one respondent 1}

The complexity of fraudulent and criminal activities has positioned many banks to engage in criminal intelligence. Our profiling is not only limited to bank staff but also customers. Every bank officer is trained to observe and detect any possible fraud activity and to treat customers as potential security treats. It is for this reason that we collect as many information as possible from customers while dealing with them. As part of the training that all staff receives, they are given basic introduction to reporting clues immediately and to notify leadership immediately any harm is detected. (KII/compliance officer/female/2021).

\subsection{Another respondent stated 2}

We work with banks to ensure that incidences of robbery are brought to the minimum. We not only observe movement of customers; we try to pick every clue from employees. Employees are vetted thoroughly before they are employed. Posting is also based on previously collected data. Effort is also made to ensure that bank staff are aware and can promptly report instances of fraud. There is no bank staff who is posted to interact with customers, that is not aware of profiling. They collect the details of customers and use it to build a credit score which shows are viable the individual can access banking services. (KII/Private security/male/2021).

\subsection{Another respondent who is a stated as follows that}

Criminal intelligence set in during recruitment process. Bank is not just an organization that renders services. It goes beyond services alone. It indulges in financial activities more especially on this regard. The staff before employment is meant to fill the entire required document and staff profiling is inclusive and also enquiries are made to know more about the staff prior deployment. As the individual makes progress on the job, more data is collected and this data is used to build the profile of the individual, both within and outside the working environment. (KII/Bank Manager/ Male/2021).

Table 2 Knowledge of the use of criminal intelligence and staff profiling amongst Nigerian Banks

\begin{tabular}{|l|c|c|}
\hline \multicolumn{1}{|c|}{ Response } & Frequency & Percentage \% \\
\hline Very wide spread & 175 & 55.4 \\
\hline Adequately wide Spread & 92 & 29.1 \\
\hline Not wide spread & 49 & 15.5 \\
\hline Total & 316 & 100.0 \\
\hline
\end{tabular}


On the extent of knowledge of these tool criminal intelligence and staff profiling among management of bank, 175 respondents which represents $55.4 \%$ of the respondents stated that it is widely spread, with 92 respondents which represents $29.1 \%$ indicated that it is adequately spread, while 49 respondents which represents $15.5 \%$ stated that it is not widely spread.

\section{Conclusion}

The study concludes that bank staff is aware and knowledgeable of criminal intelligence and staff profiling as an effective tool for fraud prevention. Beyond the awareness, bank staff are also knowledgeable on the application of criminal intelligence and staff profiling, while they also agreed that the extent of application of criminal intelligence and staff profiling in the recruitment, placement and monitoring of staff is low. However, the study recommends that Senior management of banks should be given adequate training and this training should be regularly updated on criminal intelligence and monitoring, as well as staff profiling. This would facilitate a greater uptake of credible intelligence and the prevention of bank fraud and other criminal activities.

\section{Compliance with ethical standards}

\section{Acknowledgments}

The authors wish to acknowledge the research assistants who assisted in the data collection procedure.

\section{Disclosure of conflict of interest}

There is no conflict of interest

\section{Statement of informed consent}

For this study consent was sought from the respondents who freely consented to participating in the study.

\section{References}

[1] Imoniana, J.0; Antunes, M.T.P and Formigoni, H (2013) The Forensic Accounting and Corporate Fraud. JISTEM Journal of Information Systems and Technology Management Revista de Gestão da Tecnologia e Sistemas de

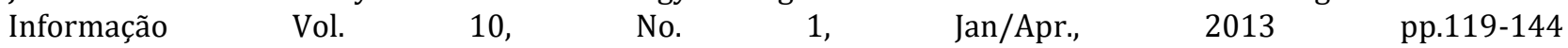
ISSN online: 1807-1775 DOI: 10.4301/S1807-17752013000100007

[2] Dada SO, Owolabi SA, Okwu AT. Forensic accounting a panacea to alleviation of fraudulent practices in Nigeria. International Journal of Business, Management, Economics and Research. 2013; 4(5): 787-792.

[3] Kanu SI, Okorafor EO. The Nature, Extent and Economic Impact of Fraud on Bank Deposit in Nigeria. Interdisciplinary Journal of Contemporary Research in Business. 2013; 4(9): 253-265.

[4] Aruomoaghe JA, Ikyume JC. Accounting for fraud in Nigeria: The banking sector in focus, International Journal of Research in Management. 2013; 3(6): 59-73.

[5] Owolabi SA. Fraud and Fraudulent Practice in Nigerian Banking Industry. An International Multi-Disciplinary Journal, Ethiopia. 2010; 4(3b): 240-256.

[6] Uchenna, C., \& Agbo, J.C. (2013). Impact of fraud and fraudulent practices on the performance of banks in Nigeria, British Journal of Arts and Social Sciences 15(1), 12-28.

[7] Ikpefan OA. Growth of bank frauds and the impact on the Nigerian banking industry. Asian Journal of Business Management. 2006; 12(7): 1-25.

[8] Odi N. Implication of fraud on commercial banks performance in Nigeria, International Journal of Business and Management. 2013; 8(15): 144-150.

[9] Idolor EJ. Bank Fraud in Nigeria: Underlying Cause, Effects and Possible Remedies, African Journal of Accounting, Economics, Finance and Banking Research. 2010; 6(6): 62.

[10] Adeyemo KA. Frauds in Nigerian banks: Nature, deep-seated causes, aftermaths and probable remedies. Mediterranean Journal of Social Sciences. 2012; 3(2): 279-289.

CBN Annual Report (2018). 